\title{
Reclaiming Kindergarten: Part II: Questions About Policy
}

\author{
Dominic F. Gullo • Kim Hughes
}

Published online: 9 November 2010

(C) Springer Science+Business Media, LLC 2010

\begin{abstract}
Part II of "Reclaiming Kindergarten" continues the discussion related to responding to the crisis in today's kindergarten. In Part II, two policy questions are posed, the answers to which seek to respond to this continuing crisis. The questions center on issues related to engaging families in kindergarten and the need to consider a new early childhood paradigm where kindergarten is part of a continuous and seamless educational experience spanning prekindergarten through third grade. As in Part I, examples of classroom practice are used to illustrate the effective implementation of these principles in a kindergarten classroom.
\end{abstract}

Keywords Kindergarten · Policy · Family involvement

\section{Introduction}

Today was Audrey's first day in full-day kindergarten. Her parents were excited to hear about Audrey's first day at school. She told her parents that she liked kindergarten and liked her teacher Mrs. Euvone. Her parents asked her if she would like a snack. Audrey said that she would but that she had to do her homework first. Audrey's homework assignment for today was to complete a worksheet in which she had to print the alphabet, both upper and lower case. She would have to do this while staying within the lines on the worksheet. The lines looked like this:

D. F. Gullo $(\bowtie)$

Drexel University, Philadelphia, PA, USA

e-mail: dfg28@drexel.edu

K. Hughes

Project Enlightenment, Wake County Public Schools, Raleigh, NC, USA
After printing the letters of the alphabet, Audrey had to circle the letters that were in her first and last name and then print her name within another set of lines on the worksheet, making sure to appropriately use upper and lower case letters. On her homework folder was a note to her parents which said, "Parents, please check and sign or initial each homework sheet after your child has completed it." There were three more homework worksheets in her folder, one each for Tuesday, Wednesday, and Thursday. After Audrey's parents signed her homework and assured her that she did a good job, Audrey looked up and said, "I just hope I get a good grade."

"Kindergarten has (emphasis mine) changed radically in the last two decades in ways that few Americans are aware of" (Miller and Almon 2009, p. 11). One only needs to look at today's most widely used data source to see what teachers, families and others are likely to find when searching for information about kindergarten. A search of the word "kindergarten" on the internet resulted in the following website topics:

- Worksheet

- Games

- Lesson plans

- Skills

- Kindergarten resources:

- Alphabet

- Numbers

- Flashcards

- Coloring books 
This reinforces to families and teachers alike, that kindergarten is all about learning specific skills and structured materials in structured ways. Missing are references to play, creativity, active learning, and music. Missing also are references to the importance of families in kindergarten children's educational experiences as well as any mention of where kindergarten fits into the graded system common in school settings. Common wisdom has it that formal schooling doesn't begin until first grade.

In Part I of "Reclaiming Kindergarten", three questions related to kindergarten practice were posed, the answers to which offered insights into the ways in which developmental integrity can be maintained in kindergarten while at the same time addressing the societal expectations of ensuring that academic standards were being met. Mrs. Wiseman, a kindergarten teacher, offered through example, classroom strategies for accomplishing this. The three questions focused on issues related to curriculum, teaching, and assessment.

In Part II of "Reclaiming Kindergarten," two kindergarten policy questions are posed. The first question addresses the importance of families in kindergarten. The second question addresses the need to consider a new early childhood paradigm where kindergarten is part of a continuous and seamless educational experience spanning prekindergarten through third grade. Again, Mrs. Wiseman offers examples of classroom strategies that exemplify the principles addressed following each question.

\section{Question \#4: How Do We Effectively Acknowledge and Support the Importance of Families In the Academic Lives of Kindergarten Children?}

Families are crucial partners in kindergarten. For many parents, kindergarten is often the first time that they will experience shared responsibility for their children with individuals who are not family members. "A positive experience can lay the foundation for later parent involvement by helping parents gain the confidence and skills needed to continue to be involved" (Chang 2010, p. 25). According to Powell and Gerde (2006), “...the kindergarten teacher is the first person at the school to have ongoing, personal contact" with families (p. 26).

In addition, it is the quality of this relationship that may set the stage for families' on-going relationships with schools. Hoover-Dempsey et al. (2005) posit that there are three crucial factors that affect families' motivation for being involved in their child's schooling:

1. There needs to be an active construction of roles for being involved. That is, parents need to believe that they should be involved. Along with this, parents need to have a positive sense of self-efficacy for helping their children learn.

2. Families have to have a perception that they are welcomed by the teacher, the student, and the school to become involved in the process of their child's educational experience.

3. The family's life context is also an important factor. Such factors as socioeconomic status, time to be involved, parents' knowledge and skills all can affect their willingness to be involved.

It is worthwhile to develop a reciprocal relationship between home and school-a relationship in which there is information exchange, shared goals for children, mutual respect and support, and a mutual understanding of expectations. A successful reciprocal home/school partnership will benefit teachers, families, and most importantly kindergarten children.

The National Parent-Teacher Association (2009) established national standards for family involvement in schools. The "PTA's National Standards for FamilySchool Partnerships" include:

1. Welcoming all families: All families are welcome in the school community.

2. Communicating effectively: Families and schools communicate effectively and meaningfully about children's learning.

3. Supporting student success: Schools and families work together to support and strengthen student learning.

4. Speak up for every child: Families are empowered to be advocates for their children to ensure that they are treated fairly and have equal access to educational opportunities.

5. Sharing power: Schools and families are full partners in informing, influencing, and creating policies, practices, and programs that affect children.

6. Collaborating with community: Families and schools work together to connect to the community resources needed in order to strengthen schools, families, and children's learning.

Research supports that if these standards are followed, positive outcomes for academic success result. In a review of research on family involvement and home-school relations, Henderson and Mapp (2002) conclude that there is a positive relationship between parent involvement and children's school success. These findings hold true regardless of children's economic or cultural situations, or the educational level of the parents. In summary, they found that:

- When parents talk to their children about school, expect them to do well ... and make sure that out-of-school 
activities are constructive, their children do better in school.

- When families engage in ways that are linked to improving learning, students make better gains.

- When schools build partnerships with families that respond to their concerns and honor their contributions, they are successful in sustaining connections that are aimed at improving student achievement.

- And when families and communities organize to hold poorly performing schools accountable, studies suggest that school districts make positive changes in policy, practice, and resources (p. 8).

Mrs. Wiseman. has worked with young children and their families for a long time. She acknowledges that language, traditions and family expectations are the primary influences on children's development. She embraces cultural and linguistic diversity as meaningful opportunities to expand children's learning. Learning is enriched and strengthened by stable, nurturing relationships within the family and community.

Mrs. W. wants families to know what is happening in the classroom and why, so she sends home a newsletter each week to provide information about their kindergarten curriculum and how it promotes children's growth and development. She includes specific activities that child and family can enjoy at home to extend learning objectives. When possible, the newsletter is sent home in the family's native language if it is not English. She is responsive to the talents and needs of individual families and offers them a flexible menu of opportunities to become involved in their child's schooling.

Mrs. W. knows that active and meaningful parent communication and enthusiastic encouragement of family participation build a mutually beneficial bridge in home/school relationships. Mrs. W. connects with families and celebrates each child with calls, emails, or notes to families to share stories of academic and social successes. Mrs. W. builds upon the strengths that each child brings to school and constructs a framework based upon success rather than failure.

\section{Question \#5: What is the Changing Role of Kindergarten Within the Wider Landscape of Early Childhood Education-Prekindergarten Through Third Grade?}

As discussed earlier, the kindergarten of today is not the kindergarten of yesterday. While many of us remember kindergarten as a place of excitement, wonder, and joyful learning, today's kindergarten children are often faced with academic pressures that in prior times were associated with older children and higher grades. Play is no longer the primary medium through which kindergarten children learn and become socialized to school. Sadly, up to $40 \%$ of schools in the United states have increased the core academics in school at the expense of recess and $25 \%$ of elementary schools have no recess at all (Connelly 2010).

With about $95 \%$ of eligible children attending kindergarten (NCES 2008), kindergarten is now considered officially "the first year of school" (Tomlinson 2009). This, in addition to the dramatic increase in the number of children now attending prekindergarten, has created a need for is a prekindergarten through third grade seamless continuum of early education. This includes an alignment of common learning standards, curriculum design, and implementation and assessment systems (NAEYC 2010; Takanishi 2010). "The vision of prekindergarten through grade three alignment must begin with the recognition that early learning does not stop at the kindergarten school door ... this era of high-stakes testing and accountability must not disrupt the successful alignment of early development to primary learning or sidetrack a child's successful developmental journey." (Connelly 2010, pp. 4-5).

According to Guernsey and Mead (2010), the education system in the United States is fragmented. They suggest that there are actually three separate systems-one for early childhood education, one for elementary and secondary education and one for post secondary education. "The first step in building a more seamless and coherent education pipeline must be the creation of seamless, high quality early education experiences for our youngest students from age three through age eight..." (Guernsey and Mead 2010, p. 3). What is called for is an integrated and high quality prekindergarten through third grade learning continuum.

Research has shown us that while a high quality prekindergarten program can increase student potential, sustained high student performance diminishes if a high quality early experiences are followed by low quality experiences in the primary grades (Currie and Thomas 2001; Lee and Loeb 1995; Magnuson et al. 2007). It should be recognized that the years that constitute prekindergarten through third grade represent a unique stage in children's educational lives, the purpose of which is to lay the foundation for critical academic and social skills (Guernsey and Mead 2010).

The Foundation for Child Development (2008) suggests the following key features of an integrated prekindergarten-third grade program are essential: 
- Access to universal high-quality prekindergarten programs for 3 and 4-year-olds; Universal full-day kindergarten;

- Curriculum and academic standards that are developmentally and culturally appropriate and aligned from prekindergarten through third grade;

- Certified and bachelor degreed teachers who are specially trained in early childhood education;

- Opportunities for teachers to plan and participate in professional development activities within and across grade levels;

- Strong school leaders who are steadfast in providing children with a seamless educational experience;

- A flexible menu of opportunities for family and community involvement.

The National Association of Elementary School Principles identified six standards for effectively designing, implementing and sustaining a prekindergarten through grade three learning continuum (Samson 2005). These standards were designed to help refocus the discussion so that all children within this learning continuum benefit. They include:

1. Support children's learning through an expanded continuum as they move from home to school and from prekindergarten and kindergarten settings into the primary grades.

2. Support families' engagement with schools to facilitate both families' and schools' understanding of early learning and development.

3. Support schools as they engage in the process of developing learning environments that are age appropriate, developmentally appropriate, secure, sufficiently staffed, and are prepared to meet the needs of a diverse group of children.

4. Support schools in providing curriculum and instructional practices that are of high-quality and that support early learners' social and emotional development.

5. Support schools in implementing assessment practices that are appropriate for the for measure the quality of learning experiences of young children and are used to improve and inform instruction.

6. Support schools in placing emphasis on early learning as part of the school culture.

Kindergarten is no longer the outsider but should be treated as a member of the "graded" family. To achieve the academic goals that have been set for the "new" kindergarten, while at the same time maintaining the practices that we know are appropriate for children of this age, closer and more productive collaboration must take place between prekindergarten, kindergarten, and the grades that follow.
Mrs. Wiseman knows that children learn best when there is an alignment among standards, curriculum, instruction, and assessment in early childhood education settings and the elementary school, within a classroom, within a grade level, and across grade levels. She maintains that curriculum should be mapped across grade levels, by utilizing child development principles and standards to align curriculum and instruction both vertically and horizontally. Curriculum should be integrated and aligned in ways that are meaningful to students and reflective of the diverse levels of strengths and needs found among early childhood age children.

Mrs. W., fellow kindergarten teachers, as well as the primary grade teachers formed a professional learning team and use their time together to intensely look into the teaching and learning process in order to become more effective in their work with students. During their time together, the teachers also discuss how what students are learning in one grade supports their learning in latter grades. This helps all of the teachers understand how each grade fits into the broader context of the early childhood learning continuum. This structure provides a context of collegiality, that supports Mrs. W. and her colleagues in improving their practice via increased reflective/collaborative time. This time is often utilized to learn new curriculum and instructional strategies and differentiated methods for interacting meaningfully with each child.

Advocacy plays a role in Mrs. W.'s success. In the era of research-based curriculum development, she continues to remind others that young children learn best when they are provided with meaningful instructional experiences that build upon and connect to their previous experiences and everyday lives. Their developmental needs and learning styles in kindergarten lend themselves to an integrated approach to curriculum rather than that of a contentspecific nature. She knows that children's learning cannot be left to chance so she educates others about both the "power of play" and the need for diversity in educational approaches, strategies, and materials to best support kindergartners' interest and ability in each learning domain.

Throughout this discussion, Mrs. Wiseman has shown us that it is possible for kindergarten children to experience success and well-being in the classroom while at the same time learning those things that will ensure school and personal achievement. Maintaining a "joyful" kindergarten does not mean that academic standards are not being met. Maintaining academic standards in kindergarten does not 
mean that developmentally appropriate teaching has to be sacrificed. Mrs. Wiseman has also shown us that teaching kindergarten does not mean teaching in isolation from others. Rather, Mrs. W. has become aware of the importance of collaboration for teaching effectively and productively-collaboration that values mutual influence. Most importantly, Mrs. Wiseman has shown us that a "joyful" kindergarten means both joyful learning and joyful teaching. Mrs. W. has shown us the path to take to turn a potential crisis into a plausible opportunity.

\section{References}

Chang, H. N. (2010). Two-generational approach. In V. Washington \& J. D. Andrews (Eds.), Children of 2020: Creating a better tomorrow (pp. 24-27). Washington, DC: Council for Professional Recognition.

Connelly, G. (2010). Prekindergarten through grade three alignment: The role of the elementary principal in building and nurturing a seamless continuum of learning. Alexandria, VA: National Association of Elementary School Principals.

Currie, J., \& Thomas, D. (2001). Early childhood intervention programs: What do we know? Journal of Economic Perspectives, 15(Spring), 213-238.

Foundation for Child Development. (2008). America's vanishing potential: The case for PreK-3rd education. New York, NY: Foundation for Child Development.

Guernsey, L., \& Mead, S. (2010). A next social contract for the primary years of education. Washington, DC: New America Foundation.

Henderson, A. T., \& Mapp, K. L. (2002). A new wave of evidence: The impact of school, family, and community connections on student achievement. Austin, TX: National Center for Family and Community Connections with Schools.
Hoover-Dempsey, K. V., Walker, J. M. T., Sandler, H. M., Whetsel, D., Green, C. L., Wilkins, A. S., et al. (2005). Why do parents become involved? Research findings and implications. The Elementary School Journal, 106(2), 105-130.

Lee, V., \& Loeb, S. (1995). Where do Head Start attendees end up: One reason why preschool effects fade out. Educational Evaluation and Policy Analysis, 17(Spring), 62-82.

Magnuson, K. A., Ruhm, C., \& Waldfogel, J. (2007). The persistence of preschool effects: Do subsequent classroom experiences matter? Early Childhood Research Quarterly, 22(1), 18-28.

Miller, E., \& Almon, J. (2009). Crisis in the kindergarten: Why children need play in school. College Park, MD: Alliance for Childhood.

National Association for the Education of Young Children. (NAEYC, 2010). Elementary and secondary education act reauthorization. Washington, DC: NAEYC.

NCES (National Center for Educational Statistics). (2008). All levels of education. In Digest of Educational Statistics, 2007 (NCES 2008-022). Online: nces.ed.gov/gprograms/digest/d07/ch-1.asp.

Parent-Teacher Association. (2009). National standards for familyschool partnerships. Retrieved from National Parent-Teacher Association website September 29, 2010, from http://www. pta.org/national_standards.asp.

Powell, D. R., \& Gerde, H. K. (2006). Considering kindergarten families. In D. F. Gullo (Ed.), K Today: Teaching and learning in the kindergarten year (pp. 26-37). Washington, DC: NAEYC.

Samson, B. (2005). Leading early childhood learning communities: What principals should know and be able to do. Alexandria, VA: NAESP.

Takanishi, R. (2010). PreK-third grade: A paradigm shift. In V. Washington \& J. D. Andrews (Eds.), Children of 2020: Creating a better tomorrow (pp. 28-31). Washington, DC: Council for Professional Recognition.

Tomlinson, H. B. (2009). Developmentally appropriate practice in the kindergarten year-Ages 5-6: An overview. In C. Copple \& S. Bredekamp (Eds.), Developmentally appropriate practice in early childhood programs serving children from birth through age 8 (3rd ed., pp. 187-216). Washington, DC: NAEYC. 